\title{
HELIUM AND ITS PLACE IN THE PETROLEUM AND NATURAL gas lease
}

\author{
B. G. MCCOMBE*
}

\section{The Problem}

Until quite recently the question whether helium is included in the conveyance of the "leased substances" by the lessor to an oil company was of little consequence. This indifference was principally due to the opinion of oil companies that the only profitable scope of operation was production of petroleum, natural gas and related hydrocarbons. In fact, until recently even natural gas was considered to be of secondary importance. There was no commercial production of helium in Canada nor were there any indications that there would be in the future. The major producing areas of helium were, and still are, Texcas and Kansas. However, there have been some significant discoveries of helium in the province of Saskatchewan in recent months. At the present time these discoveries have not been fully evaluated by the text writers, although there is little doubt that commercial production is quite feasible provided markets may be found.

The basic problem of this paper is to consider whether helium is included in the conveyancing clause of an oil company's lease form. That is to say, does the conveyancing clause give the petroleum and natural gas lessee the right to retain helium discovered on the lessor's land?

\section{The Properties of Helium}

In order to comprehend the problem, a knowledge of the properties of belium is necessary. Helium is defined by Webster's dictionary as: "one of the chemical elements, a very light, inert, colorless gas, with a chemical symbol He".

The expression "natural gas" has two dictionary meanings. Initially, to refer once again to Webster's dictionary, natural gas is defined as "a mixture of gaseous hydrocarbons, chiefly methane, occurring naturally in the earth in certain places". The text, Oil and Gas Terms, also stresses the hydrocarbon factor of natural gas. It defines natural gas as "hydrocarbons which at atmospheric conditions of temperature and pressure are in a gaseous phase." In contrast to the above definitions, natural gas can be defined as a gas which occurs naturally. Hereafter the term "ratural gas" is used in the first sense.

Helium is one of the basic elements and obviously not a hydrocarbon. It always occurs in the geseous state in nature due to its low liquification temperature. In addition, it is an inert gas in the sense that it does not combine with any other substance. Further, it is a rare gas in the same classification as neon or argon. Helium occurs, for commercial production, intermingled with natural gas and normally with nitrogen present. The reverse is not necessarily true, i.e., all natural gas deposits do not contain helium. In one sense it is an impurity in the natural gas, although in contrast to other impurities, helium is quite valuable. 
While natural gas is the only known source for commercial production of helium, this does not mean that it only occurs intermingled with natural gas. Helium does occur, although only in minute quantities, in the atmosphere and in minerals. It is quite a valuable and widely used $g^{\text {Bs }}$ and consequently is in large demand, with new uses and functions constantly being discovered.

There are two theories as to the origin of helium. The first theory is that it was obtained from the sun at the time of the earth's creation; the other, that it was created by the decay of heavier radio-active materials. This latter theory is the more popular one at the present time. The helium liberated by this decaying process rises until either it diffuses into the atmosphere or is trapped by rock formations. The same theories for the accumulation of natural gas and petroleum are applicable to helium.

A newer and simpler method for the extraction of helium from natural gas has been recently developed by Bell Telephone. This new apparatus can be attached directly to the outlet of the natural gas or to the pipeline itself. The cost of separation appears to be the main reason for the lack of commercial development from natural gas. However, this new development process supposedly shows great promise for the reduction of separation costs. Felium does not always occur in natural gas and often when it does occur, it is only in minute quantities and therefore its separation is not economically feasible.

A recent text, Helium and the Petroleum Industry, states:

Although it (helium) is found in minute quantities in most rocks and minerals, the only inportant oecurrences known in the world are associated with hydrocarbon eaces in the United States. A rocent discovery in Salkatchewan may represent the first important helium eccumulation outade of the United States.

Felium is found in both combustible and non-combustible naturally occurring gases. There are varied opinions as to the percentage of helium required to be present in natural gas before separation is economically feasible. It has been estimated by some engineers to be economically feasible to separate helium from natural gas if the content is as low as $.5 \%$ or even $2 \%$. However, U.S. Government engineers state the helium content must exceed $2 \% .^{2}$

\section{Typical Conveyancing Clauses}

In order to ascertain whether helium is included in the conveyancing clauses of the various petroleum and natural gas leases, it will be necessary to examine these conveyancing clauses in detail. Since at the present time the only known possibilities of commercial production of helium occur in the Province of Saskatchewan, the Crown lease in Saskatchewan will be considered first.

(a) Crown Leases

The Crown petroleum and natural gas lease in Saskatchewan provides in the granting clause, in part, as follows:

Jodry and Henneman (1900).

IIt chould be noted that, of least in the United genter, there is a very luerattve alternattive

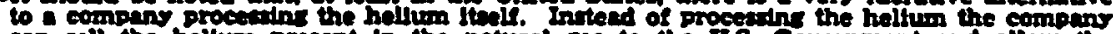
cen sell the helium preant in the notural of to the $0 \mathrm{~s}$. Covernment and allow the

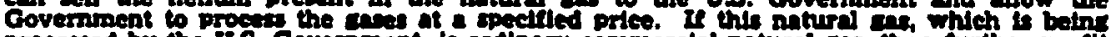

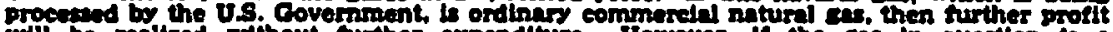

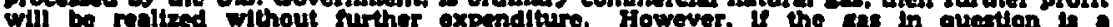
non-flaminable cen, then if ma not be economleally feasible to have a contrate of this tros. 
Together with the exclusive sight, llecnse, privilege and authority to search, dig, bore, and drill for, win, get recover, procure and carry away the petroloum; SAVING AND RESBRVING nevertheless unto the Lessor the helium in, from or found combined with, or extractable from, or that moy be obtained out of, the petroleum within or mined, won or produced from the said lands, together with full power to win, separate and extrect the same, and to treat the petroleum or subject the petroleum to any operation or process that may be necessary. effective or advisable for that purpose, and to enter upon, use and oceupy the mid lands or so much thereof and to such extent as may be neceasary and to set up and operate any mechinery, appliances or plant, and to resort to any process or operation that may be useful for any of the purposes aforesaid.

In addition to the above reservation of helium, the Saskatchewan Government has entirely separate forms for the leasing of helium and several oil companies have applied for and obtained helium leases."

Saskatchewan is the only province which has dealt specifically with helium.

\section{(b) Freehold Leases}

The freehold leases are not as explicit as the Saskatchewan Crown leases with reference to helium. Typical conveyancing clauses are:

"all the petroleum and natural gas, natural gasoline and related hydrocarbons other thin coil.".

"all potroleum, intural gas and relnted hydrocarbons (other than conl and valuable stone)."

"oll, gon, cosing-head ges and cosing-head gasoline"

The obvious solution to the problem of whether valuable gases are included in the conveyancing clause is to state in the clause that "all

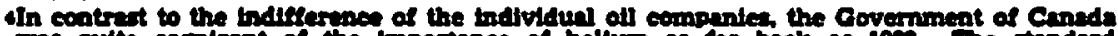

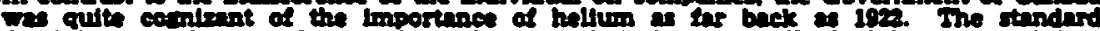

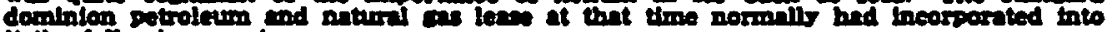
It the tollowins provivo:

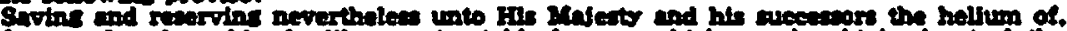

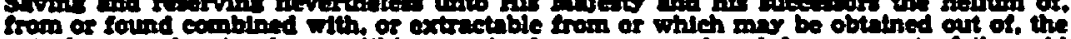

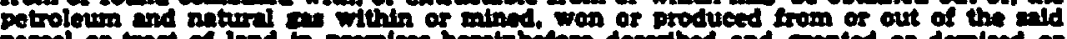
parsel or trect of innd in premines heretabetore described and cranted or demined or

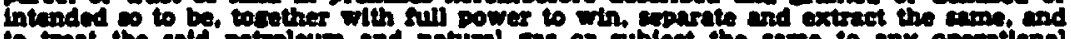

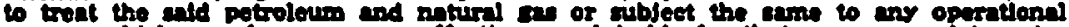

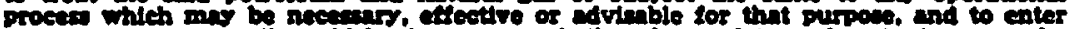
upan, use or oecups the ald lands or so mueh thorwor, ind to areh oxtiont a mor be necestary and to wt up and operate ony medhinery, applinnees or plant, and to revert to ent proces or oporatton which mir be ueful for ons of the purposes.

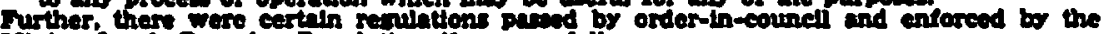

Ainins I inds Braneh. Bafulntion 11 was a lollowr:

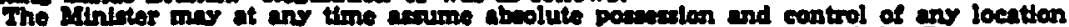

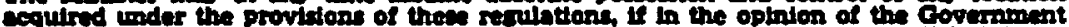

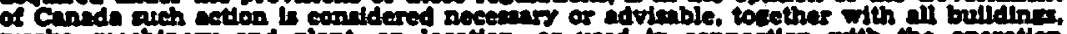

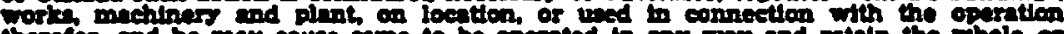
therefor. and he mor equare game to be operated in my way and retaln the whole or any part af the outurt in whteh event compensatton shin be pald to the lesere for any low or dumace autatned by hlm by reenon of the exerelse of the powers canferred by

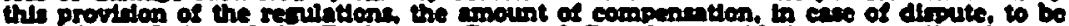

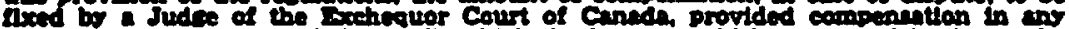

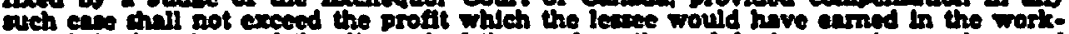
ins of the location and the dI poeal of the produce thereof, had posatedon, and control

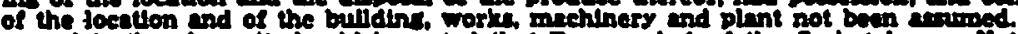

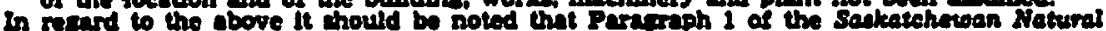
Revouree Ironder Act, 1950 (Canda) c. 41, provided. after transerring all the mines and minernis:

And the eatd land, mines and minerals, and cosaltien thatl be administered by the Province sor the purposes thereof, wbject intit the leolstation of the Proptice other:

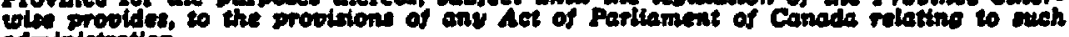
edminintration.

Paricraph a provides:

Any power of ritht. whleh, by ans contraet, lexue of other arrangeenent, of by any Act of the Parlinment of Cande relatins to ans of the linds, mine end minerall or

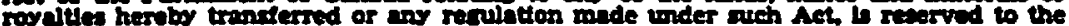
Governor in Counell for the Ainitar of the Infertor or any offeer of the Government of Canudn, my be erereled by meh oflicer of the covernment of the Provtnes. A of Alreeted iny be exereted if the Provinetil secretary of the Provines.

It should be noted that all of the Provinees hove now paraed statutes dealling directly with oll and ras. Therefore the above renilntans, includins renulatian 4, should now be repolled to impliention. 
mines and minerals" are granted. Unfortunately, the solution is not quite so simple because both lessors and lessees have objection to the inclusion of all mines and minerals. The objection on the part of the lessor is that he wishes to retain the right to certain of the mines and minerals, especially in Saskatchewan where a lucrative phosphate industry is in existence. On the other hand, the lessee oil company does not wish to be obligated to develop some of the minerals which might be found. These companies do not have the facilities for developing certain deposits such as coal.

In construing the conveyancing clause one might initially apply the "literal rule" which provides that: "The words must be interpreted in their ordinary and natural sense according to the ordinary rules of grammar and the ordinary meaning of the words." Support for this rule is found in the recent decision of the Supreme Court of Canada in Shell Oil Company v. Gibbard." If this rule is applied, there is strong possibility that helium is not included in the conveyance as a separate substance. It may, however, be included by the definition given to "natural gas."

A further rule of interpretation which should be considered is the "ejusdem generis" rule which briefly stated is: "where there are general words following specific and particular words, the general words must be confined to things of the same kind as those specified". To involse the application of the "ejusdem generis" rule there must be a distinct genus or category; the specific words must apply not to different objects of a widely different character but to something which can be called a class or lind of objects. If one examines the conveyancing clauses it is noted that the class or kind is restricted to "related hydrocarbons" and therefore will not include helium as a separate substance.

Still a further rule of interpretation to be applied to the present problem is the rule "expressio unius est exclusio alterius". This rule of interpretation stipulates that where a written instrument contains a specific provision as to a particular subject matter, the provision as to that matter which the law would imply if the instrument were silent can not be resorted to. The application of this rule definitely excludes helium as a separate substance. However as the Supreme Court of Canada noted in Turgonn v. Dominion Bank,' this rule must be applied with caution.

There is also the rule of interpretation that any ambiguity or doubt will be construed against the person who drafted the document. This rule was applied to an oil and gas lease in Shell Oil Company v. Gibbard."

It should be emphasized that the exclusion of helium is apparent only if it is considered as an entirely separate substance not connected or related to the "leased substances" in any way. This, however, is not the case. It has been noted that helium, for commercial production, occurs intermingled with natural gas.

In Canada Oil and Gas' the authors have set forth several con-

v[1981] 8.C.R. T23, 28 T.F.R. 200.

dal Finbury (2 ed.), 61.

IIIsep) 8.C.A. 6r.

abes sootrote S, rupre.

Tewts and Thompson. Forms [A.1(d)]. [A.2(a)| 
veyancing clauses for the standard freehold petroleum and natural gas lease. One clause provides:

All the potroleum, natural gas and related hydrocarbons (except coal and valuable stone), all other gases, and all minerols and substances (whether liquid or solid and whether hydrocarbons or not) produced in association with any of the foregoing or found in any water contained in any oll or gas reservolr (all hereinafter reforred to as the "leased substances").

Another clause provides:

The petroleum and any and all naturally oceurring gases inclusive or elements or compounds extracted, derived or otherwise obtained therefrom and related hydrocarbons other than coal (so much of which as are subject to this Lease and Grant at any given time being hereinafter sometimes called "Petroleum Substances").

These conveyancing clauses would appear to include helium.

Whether helium is included in the ordinary lease in conveyancing clauses has never been examined by either the courts of Canada or the United States. However, similar problems have arisen with respect to other mineral substances. In New York State Natural Gas Corporation v. Swan Finch Gas Development Co., ${ }^{10}$ it was held that the reservation of "all coal, coal oil, fine clay and other minerals of every kind and character" did not include natural gas. The basis of the decision was that by the application of the "ejusdem generis" rule natural gas was excluded.

Another case illustrating the application of the "ejusdem generis" rule is Fleming Foundation et al v. Teras." The reservation in this case was "gas and other minerals". It was held by the courts that subsurface water was not included in that phrase.

These decisions indicate certain situations and clauses where the substances in question were not included in the conveyancing clauses. A contrasting decision is Lone Star Gas Company v. Stine where it is stated: 12

An examination of the several instruments clearly discloses that the gas conveyed was not limited to any partteular kind or character of gas, but the conveyance is all embrooing as regards gas and covers and includes "all natural ges".

The judge also stated:

The term "all natural gas" would include all the substances that come from the well as a gas and that regardics of whether such gas be wet or dry. It is undisputed in evidence that the term "natural gas" includes numerous elements or component parts but the very langrage of the conveyance is such as to include therein all these component parts which were in geseous farm when they came from the woll.

In this case the owner of the land leased to the oil company "all our rights, interest, etc., in all natural gas in and under the following tract, etc.". Gas was produced and in the process for pressurizing for transportation by a pipeline, gasoline was formed. The action was for royalty payment by the freehold owmer. The trial judge decided in favor of the lessee that there was no need to pay royalties. His decision was reversed by the Civil Court of Appeals and then restored by the Texas Commission of Appeals. One of the important points in this case was that the gasoline oply separated from the natural gas by a manufacturing process (con-

2001 a Can Reporter. Vol. 12. p. 218.

11011 Cs: Beportot Vol, 18, D. az7.

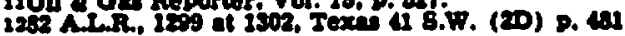


densation and pressurization) but was originally in a gaseous form when it left the well. There is an important annotation following this case. Although this annotation bears mainly on the question of casinghead gas being oil or gas, it is illuminating to note certain aspects which are of importance for the present problem. At page 1304 of the report it is stated:

The question fundamentally im't an academic or selentific one, to be solved by an analysis of the component parts of the gas, but is a question of construction of the terms of the lease or other contracts, in the effort to determine the intent of the parties thereto, and the popular rather than seientific understanding of the term is of more importance urually in determining the riphts of the parties.

It is readily apparent that one cannot state with certainty whether the various conveyancing clauses include or exclude helium found while exploring for or developing oil and natural gas wells. On the whole the rules of interpretation lead to the conclusion that helium, as a separate substance, is not included in the various conveyancing clauses unless they are drafted in a manner similar to those quoted from Canadian Oil \& Gas." Other lease clauses should be examined for the light which they may throw on the question of interpretation.

One major oil company has a lease which provides as follows:

(c) Plant Producte-12\%\% of the amount actually recelved by the lescee on plant products obtained by absorption or other process from notural ges produced from the ald linds.

Quite possibly the clause in reference to the plant products is wide enough to cover the extraction of helium and the lessee could argue that it is entitled to by-products such as helium by implication-i.e. that the clause amends the conveyancing clause by implication.

The lessee could also assert that belium or other similar substance would be included in the conveyance as a component of natural gas. The United States case of Lone Star Gas Co. v. Stine ${ }^{24}$ supports this view. There is also support for such an argument in the text, Helium in Canada -Mines Branch. ${ }^{20}$ The author states:

The chief constituents of natural ges are usually methane, ethane, sltrogen, with smaller amounts of carbon dioxide, oxyzen, hellum and higher hydrocarbons.

Another argument is that if helium is not a constituent of natural gas then it is at the least an impurity which may be retained by the lessee after extraction. This argument is especially applicable to belium which only occurs, for commercial production, intermingled with natural gas, and is substantiated by judicial decisions rendered by the Privy Council and American courts.

In the American case of Guffy v. Stroudse an oil company had the right to drill for an oll well but held no rights for gas. The company drilled the well and found only gas. The owner of the gas brought action to shut in the well in order to prevent waste. There was a counterclaim by the drillers for one-half the price of the drilling costs. An injunction was granted but the court refused to force the owner of the

12supre, noto 9.

145upre, note 12.

30.4 worthy, Bellum in Canade-Mines Branch (19n8).

1664 A.thin, 700 (Texis). 
gas to pay one-half the cost of drilling as he was not appropriating the well to his own use. The headnote states:

The right conferred by an oll lease to drill for oll carries with it by implleation the right to tap the gas pocket and bring to the surface so much of the gas as is necesiany in the proper drilling for ail

The court did not elaborate on the question of the ownership of this gas which is brought to the surface while drilling for oil. In view of the fact that no oil had been discovered the answer to this question was not necessary to the decision. Correlating this decision with the present problem the decision could indicate that the lessee of "petroleum, natural gas and related hydrocarbons (other than coal and valuable stone)" is entitled to bring to the surface any substance, such as helium, which is intermingled with the said "leased substances". This of course still leaves unanswered the question of the ownership of these intermingled substances. In the annotation to Guffey v. Stroud reference is made to Kier v. Peterson'i which was an action in trover against a certain company which had the right to bore salt wells. In the course of drilling these salt wells oil was encountered, and the plaintiff claimed ownership. The court dismissed the trover action and stated:

The presence therefore of petroleum or mineral oll is naturally to be expected in the selt formatton of the Allegheny Mountains, and, although its great value has not been fully appreciated until within a few years, still if it comes up as in the present instances, with the brine of the well which was opened in pursuance of and must be regularly worked by the express stipulation of the lease, it must belong to the leasee, who must separate it from the salt and either prepare it for market or let it run to waste.

The above quotation leaves little doubt as to the ownership of substances intermingled with leased substances. Therefore, the cases of Kier v. Peterson and Guffey v. Stroud indicate that the lessee has the right and ownership of all substances, whether hydrocarbons or not, which are intermingled and brought to the surface with the leased substances.

The Privy Council decision in Borys v. Canadian Pacific Railway and Imperial Oil Limited"s is extremely important and will be examined in some detail.

The plaintiff was the registered owner of a certain quarter section of land. The action itself was for a declaration that the plaintiff was the owner of all the natural gas within or under said lands and in addition, for an injunction restraining the defendants from removing, etc., said gas. The defendants counterclaimed for, inter alia, a declaration that the oil company had the right to remove and dispose of such natural gas as might be necessary or incidental to the working, winning and carrying away of the petroleum. The plaintiff's title was derived through an intervening transfer from a transfer made by the railway company in 1918 in pursuance of an agreement for sale entered into in 1906 . Said agreement and transfer and certificate of title which issued thereon contained the following reservation: "reserving thereout all coal, petroleum and valuable stone." In 1949 the Canadian Pacific Railway Company leased to the defendant (respondent) oil company, the petroleum within, on or under said lands and "the right to work, win and carry away same". The issue was whether the reservation included 
natural gas. The Privy Council held that it did not, saying that the word "petroleum" in the circumstances "included gas in solution and liquid as it exists in the earth". Lord Porter stated at p. 552:

When endeavoriog to ascortain the meaning which is to be attributed to petroleum in the original reservation, it becomes necessery to decide who are the persons whose use of the word is to determine the sense in which it is employed in the relevant document inasmuch as a chemiat and laboratory expert may attribute to it a meaning different from that which the lay mind would adopt. As has been aid, the chemical contents of the petroleum and the natural gas found in the field are the same and rogarded scientifically the substances are therefore the same. But a seientific similarity of substance does not eatablish that the materials are themselves rightly to be deseribed by the same name. The proper approsch, said the appelitant, is to ascertain the meaning of the word in the mouths of those non-seientific persons who are concerned with its use, such as hind owners, buriness men and engineers, and to be guided by them as to the true construction of the reservation. The vernacular, not the seientific meaning is, he maintoins, the true one, and in support of this contention he calls attention to the observetion of Lord Halsbury in Clasgore Corporation v. Parlest when he says of mines and minerals that in construing the expression It has to be determined what these words mean in the vermeular of the mining world, the commercial world and land-owners when the grant was made. This method of interpretation has been repeated and sccepted more than once and their lordships arree that, where it con be ascertalned that a particular vernacular meaning is attributed to the words under cireumstances similar to those in which the expression to be construed is found, the vernacular meaning must prevail over the scientific. But the distinction is not a ripid one to be applied without regard to the elreurnstences in which the word is used. It was sald by Lord Watson in the seme case at page 675 "mines and minerels" are not definite terms; thes are suseoptible of limitation or expandion, ecoording to the Intentton with which they are used. In their lordahips' viow the same observations are true of the meaning of petroleum. It may vary according to the cireumitances in which it is used.

Again at page 556 Lord Porter continues:

Dr. Naurs, however, is expreasing the opinion of the expert, whereas, as the appellant inaists and their lordships arree, it is in the vernseular use that the true solution is to be found. The chemist make a distinction between different contents of the liquid substance and resolve it into its constituent parts but such treatment is purely seientific and in no sense bosed on the view of the ordinary man.

And at page 561:

The gas is not an exhalation of the oll, not is it held In solution by the oil to any conadderable extent. The gas and oll are in their chemical composition no doubt both hydrocarbons, but they are distinct and different products, and therefore it could not be contended successfully, their lordships thinie, that the wonds "springs of oll" cover this natural ges, admply because both are found in some cases to impregnate the same subterranean porus stratum, and that when this stratum is tapped by a pipe or boring leading to the surface, the gas in its eseape to the upper air helps to bring up to the surfece with it come of the oil.

The court stressed that the leased substances are not to be examined after they reach the surface but rather as they exist "in situ". This method of examining the leased substances enhances the lessee's position in regard to the retaining of any helium which is discovered. If the natural gas is examined on the surface, the helium, due to it being the second lightest gas known, will separate from the other components of natural gas. However, while still contained beneath the surface of the earth, the helium actually forms part of the natural gas itself, either as a component or as an impurity (depending on the definition given to natural gas).

A further important observation made by the Privy Council which

10(2849), is A.C. 6r. 
should be stressed is the statement to the effect that although natural gas and petroleum are two distinct substances the lessee still had the right to retain the natural gas which was found dissolved in the petroleum.

Their Lordships also pointed out that if a substance has a particular meaning in the mind of the layman then the meaning which must govern is the vernacular and not the scientific. This statement of law clarifies the situation in the sense that helium is not necessarily excluded from the above-described conveyancing clauses merely because it is not of the same chemical family as petroleum, natural gasoline, or related hydrocarbons.

\section{Conclusion}

In conclusion, it is submitted that in the unlikely event that helium is discovered as a separate substance the typical conveyancing clauses are inadequate to convey the helium so found to the lessee. If helium is intermingled with natural gas there is a strong possibility, and even a marked probability, that helium is in fact conveyed by the conveyancing clauses in question. First, even apart from judicial decisions, helium would be included in the conveyancing clauses because in fact it forms a part of one of the leased substances, namely natural gas, whether considered as a component of natural gas such as methane, or as an impurity. Second, the judical decisions support this view.

The judge considering Lone Star Gas v. Stine ${ }^{20}$ stated that the term "all natural gas" included all substances "that came from the well as a gas". This case is analogous to our present problem, since casing-head gas, the subject matter of that dispute, only separated out from the natural gas by a form of a manufacturing process. A form of a manufacturing process is also required to separate helium from the natural gas.

The case of Guffey v. Stroud2t indicates that a lessee has the right to bring up all substances intermingled with the leased substances. The ownership of the intermingled substances was stated to be in the lessee in Kier v. Peterson." Therefore there seems to be little doubt that if these American decisions were followed by our courts the lessee would have the right to produce, separate and market all substances naturally intermingled with the leased substances, which would include hellum. This approach is strongly supported by the Privy Council in Borys v. Canadian Pacific Railway. ${ }^{28}$ Their Lordships stated that the leased substances are to be examined as they exist in situ rather than after they have reached the surface. This is an extremely important statement for our purposes as helium remains intermingled with the natural gas when it is in situ. The Privy Councll also stated that despite the fact that natural gas and petroleum are two distinct substances, the lessee still had the right to retain all natural gas dissolved in the petroleum. If this statement is applied to the present problem it would appear to be logical to assume that all helium intermingled with natural gas can, when the natural gas is produced, be retained by the lessee. 